\title{
A Novel Synthesis of Zinc Borates from a Zinc Oxide Precursor via Ultrasonic Irradiation
}

\author{
Ali Can Ersan, ${ }^{1}$ Meral Yildirim, ${ }^{1}$ Azmi Seyhun Kipcak ${ }^{1}$ and Nurcan Tugrul ${ }^{1, *}$ \\ Yildiz Technical University, Davutpasa Campus, Faculty of Chemical and Metallurgical Engineering, \\ Department of Chemical Engineering, Davutpasa Street No.127, 34210 Esenler, Istanbul, Turkey \\ * Corresponding author: E-mail: ntugrul@yildiz.edu.tr \\ telephone number: +90-212 3834771, fax number: $+90-2123834725$
}

Received: 25-08-2016

\begin{abstract}
In this study, zinc borate hydrate $\left(\mathrm{Zn}_{3} \mathrm{~B}_{6} \mathrm{O}_{12} \cdot 3.5 \mathrm{H}_{2} \mathrm{O}\right)$ was synthesized from zinc oxide $(\mathrm{ZnO})$ and boric acid $\left(\mathrm{H}_{3} \mathrm{BO}_{3}\right)$ via a novel method of ultrasonic irradiation. X-ray diffraction (XRD), Fourier-transform infrared spectroscopy (FT-IR) and Raman spectroscopy were used to characterize the synthesized products. Scanning electron microscopy (SEM) was used to determine the effects of reaction time and reaction temperature on the morphology of the products. Thermal dehydration kinetics were studied using thermal gravimetry and differential thermal gravimetry analysis (TG/DTA). The Doyle and Kissinger non-isothermal kinetic methods were used to analyse the TG/DTA data. The XRD results confirmed the successful synthesis of $\mathrm{Zn}_{3} \mathrm{~B}_{6} \mathrm{O}_{12} \cdot 3.5 \mathrm{H}_{2} \mathrm{O}$ at a range of reaction temperatures and times. Additionally, FT-IR and Raman analysis of the products identified peaks specific to zinc borate. Using the methods of Doyle and Kissinger, the activation energies of thermal dehydration of zinc borate were found to be $341.61 \mathrm{~kJ} / \mathrm{mol}$ and $390.17 \mathrm{~kJ} / \mathrm{mol}$, respectively.
\end{abstract}

Keywords: Zinc borate, ultrasonic irradiation, dehydration, thermal analysis

\section{Introduction}

Zinc borate compounds (ZB) are widely applied in fields ranging from the polymer industry to the pharmaceutical industry. ZB can be used in plastic, rubber, ceramics, paint, wire, electrical insulation, wood, and cement applications. Zinc borates are commercially important inorganic hydrated borates and function as flame and fire retardants. Additionally, zinc borates are used as an additive in the polymer, coating and pigment industries due to their smoke suppressing and anticorrosive properties. ${ }^{1-8}$

Because of their potential use in many industrial applications, in the last decade, several studies were carried out to produce zinc borate from different precursors and using a variety of methods. Sawada et al. studied the synthesis of $\mathrm{ZB}$ in a two-step reaction of zinc oxide $(\mathrm{ZnO})$ and boric acid $\left(\mathrm{H}_{3} \mathrm{BO}_{3}\right)$ at $60{ }^{\circ} \mathrm{C}$ for $1.5 \mathrm{~h}$ to form crystals, followed by heating to $90{ }^{\circ} \mathrm{C}$ for $4 \mathrm{~h}$ to enhance crystal growth. ${ }^{9}$ Gao and Liu synthesized ZB minerals at the boiling point of the solvent and with a reaction time of $11 \mathrm{~h}^{.10}$ Chen et al. examined the production of $\mathrm{ZB}$ nanoflakes $\left(2 \mathrm{ZnO} \cdot 2 \mathrm{~B}_{2} \mathrm{O}_{3} \cdot 3 \mathrm{H}_{2} \mathrm{O}\right)$ via the coordination and homoge- neous precipitation of ammonia, zinc nitrate $\left(\mathrm{Zn}\left(\mathrm{NO}_{3}\right)_{2}\right.$. $\left.6 \mathrm{H}_{2} \mathrm{O}\right)$, and borax $\left(\mathrm{Na}_{2} \mathrm{~B}_{4} \mathrm{O}_{7} \cdot 10 \mathrm{H}_{2} \mathrm{O}\right){ }^{2}$ Zheng et al. synthesized zinc borate in the form of $4 \mathrm{ZnO} \cdot \mathrm{B}_{2} \mathrm{O}_{3} \cdot \mathrm{H}_{2} \mathrm{O}$ by the addition of $\mathrm{Zn}\left(\mathrm{NO}_{3}\right)_{2} \cdot 6 \mathrm{H}_{2} \mathrm{O}$ to a mixture of $\mathrm{Na}_{2} \mathrm{~B}_{4} \mathrm{O}_{7} \cdot 10 \mathrm{H}_{2} \mathrm{O}$ and a phosphate ester at $70{ }^{\circ} \mathrm{C}$ for $7 \mathrm{~h} .{ }^{11}$ Gürhan et al. studied the production of 3.5 mole hydrated zinc borate and investigated the effects of the synthesis conditions on the final product properties considering the reaction kinetics. ${ }^{3}$ Tugrul and Acarali studied the effects of different modification agents on obtaining hydrophobic zinc borate hydrate minerals at $50-120{ }^{\circ} \mathrm{C}$ and in $1-5$ h. ${ }^{12}$ Bardakci et al. synthesized zinc borate by the reaction of zinc oxide and boric acid in the absence and presence of the surfactant cumene-terminated poly styrene-co-maleic anhydride (PSMA).$^{13}$ Acarali et al. produced zinc borate from zinc oxide and boric acid reference materials at $95{ }^{\circ} \mathrm{C}$ in $1-5 \mathrm{~h}$ using a zinc borate reference material as seed and researched the effects of modifying agents and reaction conditions on hydrophobicity and yield. ${ }^{14}$

Sonochemistry is a green synthesis method for inorganic materials. In sonochemical reactions, acoustic cavitation increases the surface area for mass transfer between 
reactants and thus increases the reaction rate. As a result, high productivity can be achieved even at low reaction temperatures and shorter reaction times. ${ }^{15,16}$

In the literature, several studies can be found on the use of sonochemistry for the preparation of different materials, such as $\mathrm{ZnO},{ }^{17}$ zeolites, ${ }^{18} \mathrm{Sb}_{2} \mathrm{~S}_{3},{ }^{19} \mathrm{TiO}_{2},{ }^{20} \mathrm{NaB}(\mathrm{OH})_{4}$ $\cdot 2 \mathrm{H}_{2} \mathrm{O}^{21}$ and magnesium borates. ${ }^{22}$ However, sonochemistry has not been applied for the synthesis of zinc borates. Our group has published two studies on the production of zinc borates via the ultrasonic route. In the study of Ersan et al., ${ }^{23}$ we determined the optimum molar ratio of $\mathrm{ZnO}$ and $\mathrm{H}_{3} \mathrm{BO}_{3}$, which forms the basis of this study. In the study of Vardar et al., we determined the optimum molar ratio of $\mathrm{Zn}_{5}\left(\mathrm{CO}_{3}\right)_{2} \cdot(\mathrm{OH})_{6}$ and $\mathrm{H}_{3} \mathrm{BO}_{3}{ }^{24}$

Thermal decomposition of metal borates usually includes dehydration as a consequence of removing the water of crystallization from the main structure. The characteristic features of the dehydration of metal borates should be known to enable the design of dehydration equipment and to decrease the mass of materials required, hence decreasing transportation costs Therefore, the thermal dehydration kinetics of several important zinc borates should be studied.

From the literature, it is seen that the hydrothermal synthesis of zinc borate compounds requires a high temperature $\left(\geq 95^{\circ} \mathrm{C}\right)$, long reaction times $(\geq 2 \mathrm{~h})$ and several different modification agents (i.e., polyethylene glycol, oleic acid).

Starting from the optimum molar ratio of $\mathrm{ZnO}$ and $\mathrm{H}_{3} \mathrm{BO}_{3}$ determined in the study of Ersan et al., ${ }^{23}$ the current study shows the effects of reaction temperature and reaction time on the synthesis of zinc borates. The novel aspect of this paper is the production of ZB employing ultrasonic irradiation to decrease the reaction temperature and reaction time to achieve a green chemical synthesis. The ZB produced was characterized by X-ray diffraction (XRD), Fourier transform infrared (FT-IR) spectroscopy and Raman spectroscopy, while surface morphologies were determined by scanning electron microscopy (SEM). In addition, the activation energies of the thermal dehydration of ZB are reported.

\section{Materials and Methods}

\section{1. Characterization of the Raw Materials}

Zinc oxide $(\mathrm{ZnO})$ was obtained from Sigma Aldrich (ReagentPlus®, powder, $<5 \mu \mathrm{m}$ particle size, $99.9 \%$, CAS Number 1314-13-2) (Interlab, Istanbul, Turkey), and $\mathrm{H}_{3} \mathrm{BO}_{3}$ was obtained from Bandirma Boron Works (99.9\%) (Eti Maden, Balıkesir, Turkey). $\mathrm{H}_{3} \mathrm{BO}_{3}$ was ground using a Retsch RM 100 agate mortar (Retsch GmbH \& Co KG, Haan, Germany) and sieved (Fritsch analysette 3 Spartan pulverisette 0 vibratory sieve-shaker (Fritsch, Idar-Oberstein, Germany)) to obtain a particle size below $75 \mu \mathrm{m}$. Reactants were identified by XRD (Phi- lips PANalytical Xpert Pro XRD (PANalytical B.V., Almelo, the Netherlands)), which uses a $\mathrm{Cu}-\mathrm{K} \alpha$ tube $(\lambda=$ $0.153 \mathrm{~nm}$ ). The XRD analysis parameters were $45 \mathrm{kV}, 40$ $\mathrm{mA}$, step size of $0.03^{\circ}$, time step of $0.5 \mathrm{~s}$, scan speed of $0.06^{\circ} \mathrm{C} / \mathrm{s}$, and 2 theta scan range of $7-90^{\circ}$. The Inorganic Crystal Structure Database (ICSD) patterns were scanned with the X'Pert HighScore Plus computer programme.

\section{2. Zinc Borate Synthesis}

Several pre-experiments conducted to determine the optimum molar ratio of the $\mathrm{ZnO}(\mathrm{Z})$ to $\mathrm{H}_{3} \mathrm{BO}_{3}(\mathrm{H})$ reactants found the ratio to be $1: 3 .^{23}$ The expected reaction equation is given in eqn. (1):

$$
\begin{aligned}
& \mathrm{ZnO}+3 \mathrm{H}_{3} \mathrm{BO}_{3}+x \mathrm{H}_{2} \mathrm{O} \rightarrow 1 / 3\left(\mathrm{Zn}_{3} \mathrm{~B}_{6} \mathrm{O}_{12} \cdot 3.5 \mathrm{H}_{2} \mathrm{O}\right) \\
& +\mathrm{H}_{3} \mathrm{BO}_{3}+y \mathrm{H}_{2} \mathrm{O}
\end{aligned}
$$

For the experiments, a batch type reactor with a capacity of $100 \mathrm{~mL}$ equipped with a temperature controller and a cooling jacket was used. Distilled water used in the experiments was obtained from GFL 2004 (Gesellschaft für Labortechnik, Burgwedel, Germany). In the synthesis, 0.1262 moles of $\mathrm{H}_{3} \mathrm{BO}_{3}$ was dissolved in $25 \mathrm{~mL}$ of distilled water and heated to the desired temperature in the batch reactor. Then, 0.0420 moles of $\mathrm{ZnO}$ and commercial zinc borate seed obtained from a local supplier (Melos A.S.., Istanbul, Turkey) were added $(1 \% \mathrm{w} / \mathrm{w}$ as $\mathrm{H}_{3} \mathrm{BO}_{3}$ ). The synthesis was started by the direct immersion of a Bandelin Sonopuls HD $2070(20 \mathrm{kHz})$ ultrasonic homogenizer (Bandelin electronic $\mathrm{GmbH} \& \mathrm{Co}$. KG, Berlin, Germany). At the beginning of the reaction, cooling water was used to maintain a constant temperature given the amount of energy that the ultrasonic probe provides to the reaction medium. After the determined reaction time, the slurry liquid was filtered (chm F2044 grade (Ashless, slow filter speed) $90 \mathrm{~mm}$ blue ribbon filter paper (Chmlab, Barcelona, Spain)), and the crystallized contents on the filter paper were washed with distilled water $\left(\sim 70^{\circ} \mathrm{C}\right)$ several times in order to remove the unreacted $\mathrm{H}_{3} \mathrm{BO}_{3}$. The filtrate was dried (EcoCELL LSIS-B2V/EC55 model incubator (MMM Medcenter Einrichtungen GmbH, Planegg, Germany)) at $105^{\circ} \mathrm{C}$ for $12 \mathrm{~h}$. The reaction procedure is schematically shown in Fig. 1.

Reaction temperatures and reaction times were varied between $80-90{ }^{\circ} \mathrm{C}$ and $40-55 \mathrm{~min}$, respectively, to determine the effects of those parameters on the synthesized products.

\section{3. Zinc Borate Characterization Studies}

In the XRD analysis, the same diffraction parameters were used as were used in the characterize the raw materials. The 2 theta range was $10-70^{\circ}$.

In the FT-IR and Raman analyses, a PerkinElmer Spectrum One (PerkinElmer, MA, USA) with a universal 
Equipments (Process) 1. Balance (Weighing)

2. Batch Reactor

3. Filtration and washing processes

4. Incubator

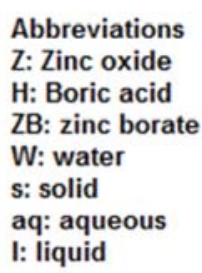

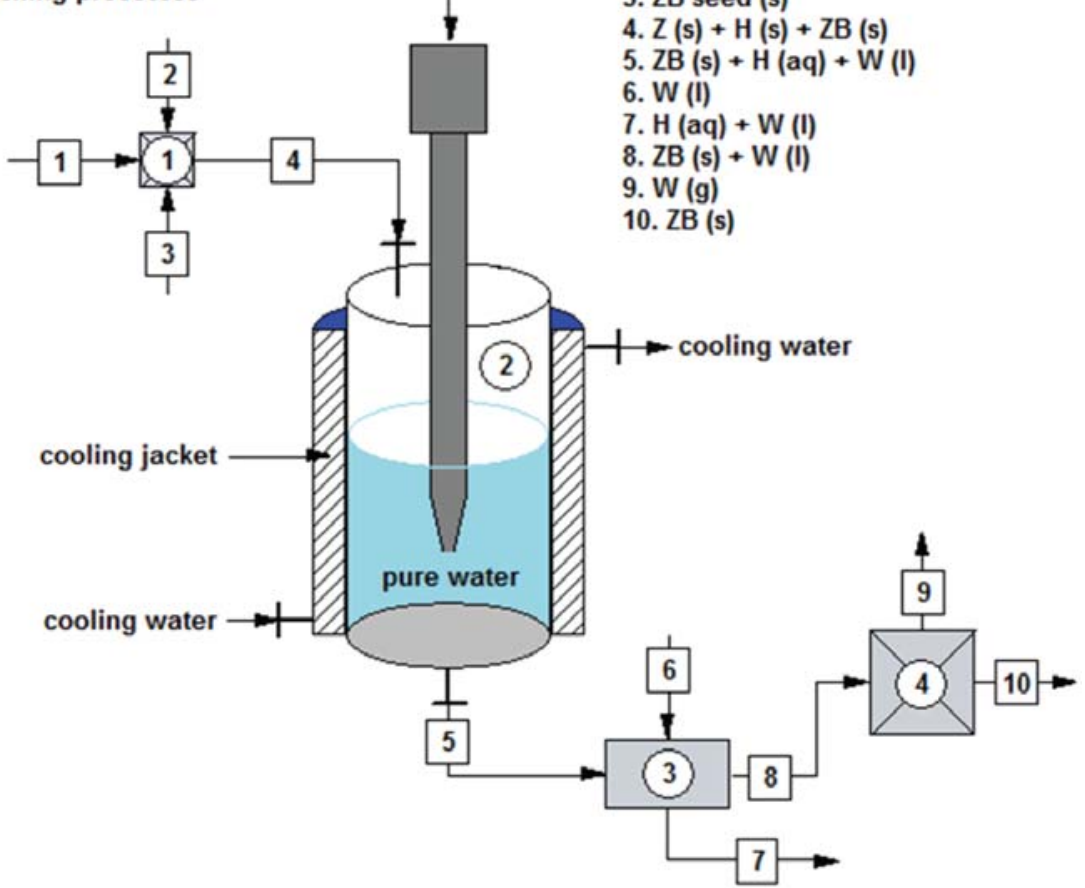

Streams

1. $Z$ (s)

2. $\mathrm{H}(\mathrm{s})$

3. ZB seed (s)

4. $\mathrm{Z}(\mathrm{s})+\mathrm{H}(\mathrm{s})+\mathrm{ZB}(\mathrm{s})$

(s) $+\mathrm{H}(\mathrm{aq})+\mathrm{W}(\mathrm{I})$

10. ZB (s)

Fig. 1. Reaction scheme of the pure zinc borate synthesis

attenuated total reflectance (ATR) sampling accessory-Diamond/Zn and a Perkin Elmer Raman Station 400F (PerkinElmer, CT, USA) were used, respectively. The spectrum ranges were selected between 1800-650 and $1800-250 \mathrm{~cm}^{-1}$ for the FT-IR and Raman analyses, respectively. For the FT-IR analysis, 4 scans were averaged, and the resolution was set to $4 \mathrm{~cm}^{-1}$. For the Raman analysis, an exposure time of $4 \mathrm{~s}$ with 4 exposures and a data interval of $2 \mathrm{~cm}^{-1}$ were used.

For the SEM analysis, a CamScan Apollo 300 FieldEmission SEM (CamScan, Oxford, UK) was used. Before morphological analysis, the synthesized zinc borates were coated with Au/Pt using a Polaron Range SC7640 model Sputter Coater (Quorum Technologies Ltd., East Sussex, UK). After the coating, the morphological structure of the products was investigated at $15 \mathrm{kV}$ using the back scattered electron (BEI) detector.

\section{4. Zinc Borate Thermal Dehydration Kinetic Studies}

The thermal properties of the zinc borate sample synthesized at $90^{\circ} \mathrm{C}$ and for $55 \mathrm{~min}$ were analysed using a PerkinElmer Diamond TG/DTA (PerkinElmer, MA, USA). Heating rates of $5,10,15$ and $20^{\circ} \mathrm{C} / \mathrm{min}$ were applied in an inert atmosphere $\left(\mathrm{N}_{2}\right)$ between the temperatures of 105 and $550{ }^{\circ} \mathrm{C}$. The activation energy $\left(E_{a}\right)$ and preexponential factor $\left(k_{0}\right)$ for dehydration were calculated us- ing the Doyle and Kissinger non-isothermal kinetic methods.

In the method of Doyle, the values of $-\log \beta$ are plotted against $1 / T_{m}$ and the activation energy can be found from the slope of the resulting line. The equations for this method are given in eqn. (2) and (3):

$$
\begin{aligned}
& -\log (\beta)=0.4567 \times \frac{E_{a}}{R T_{m}}+\text { constant } \\
& k_{0}=\frac{\beta \times E_{a}}{R \times T_{m}^{2}} \times e^{\frac{E_{a}}{R \times T_{m}}}
\end{aligned}
$$

where $\beta\left({ }^{\circ} \mathrm{C} \cdot \mathrm{min}^{-1}\right)$ is the heating rate, $E_{a}\left(\mathrm{~J} \cdot \mathrm{mol}^{-1}\right)$ is the activation energy, $\mathrm{R}\left(\mathrm{J} \cdot \mathrm{mol}^{-1} \cdot \mathrm{K}^{-1}\right)$ is the universal gas constant, and $T_{m}\left({ }^{\circ} \mathrm{C}\right)$ is the temperature at the peak of the DTA curve.

In the method of Kissinger, the values of $-\log$ $\left(\beta / T_{m}{ }^{2}\right)$ are plotted against $1 / T_{m}$, and activation energy can be found from the slope of the line. In this method, $T_{m}$ $\left({ }^{\circ} \mathrm{C}\right)$ is temperature at the peak point of the differential thermal gravimetry (DTG) curve. The equation of the method is given in eqn. (4):

$$
-\log \left(\frac{\beta}{T_{m}^{2}}\right)=\ln \left(\frac{k_{0} \times R}{E_{a}}\right)-\frac{E_{a}}{R T_{m}}
$$




\section{5. Zinc Borate Thermal Conversion}

To identify the compound produced after thermal analysis, a zinc borate sample synthesized at $90{ }^{\circ} \mathrm{C}$ and for 55 min was calcined in a ProTherm MOS 180/4 hightemperature furnace (Alserteknik, Ankara, Turkey) by heating at $10{ }^{\circ} \mathrm{C} / \mathrm{min}$ to $550{ }^{\circ} \mathrm{C}$ in a flowing $\mathrm{N}_{2}$ atmosphere $(5 \mathrm{~mL} / \mathrm{min})$. After calcination, the sample was washed with distilled water several times and dried at $105{ }^{\circ} \mathrm{C}$ in an EcoCELL LSIS-B2V/EC55 model incubator. The sample was then analysed by XRD.

\section{6. Zinc Borate Reaction Yields}

Reaction yields were calculated using the same procedures given in the literature. ${ }^{22} \mathrm{ZnO}$ was defined as the key reactant. The synthesis reaction was repeated three times for each condition, and the results were averaged to obtain the yield and standard deviation. The overall reaction yield based on molar flow rates, $\mathrm{Y}_{\mathrm{D}}$, is defined as the ratio of the moles of product formed at the end of the reaction, $\mathrm{N}_{\mathrm{D}}$, to the number of moles of the key reactant that have been consumed. $\mathrm{N}_{\mathrm{A} 0}$ and $\mathrm{N}_{\mathrm{A}}$ are the initial and final moles of the key reactant, respectively. For a batch system, the reaction yield was calculated using eqn. (5). ${ }^{25}$

$$
Y_{D}=\frac{N_{D}}{N_{A 0}-N_{A}}
$$

\section{Results and Discussion}

\section{1. Results of the Raw Material Characterization}

According to the $\mathrm{XRD}$ results, $\mathrm{ZnO}$ was identified as "zinc oxide ( $\mathrm{ZnO})$ " with powder diffraction file (pdf) number of "01-079-2205", and $\mathrm{H}_{3} \mathrm{BO}_{3}$ was identified as "sassolite $\left(\mathrm{H}_{3} \mathrm{BO}_{3}\right)$ " with pdf no. of "01-073-2158". The commercial zinc borate seed was identified as "zinc oxide borate hydrate $\left(\mathrm{Zn}_{3} \mathrm{~B}_{6} \mathrm{O}_{12} \cdot 3.5 \mathrm{H}_{2} \mathrm{O}\right)$ " with pdf number "00-035-0433".

\section{2. XRD Results of the Synthesized Zinc Borates}

XRD results of the synthesized zinc borates are given in Table 1.

According to the XRD results, zinc borate formation did not occur after $40 \mathrm{~min}$ of reaction at $80{ }^{\circ} \mathrm{C}$ nor after 40 min of reaction at $85{ }^{\circ} \mathrm{C}$. At reaction temperatures and times of $80{ }^{\circ} \mathrm{C}-45 \mathrm{~min}, 80{ }^{\circ} \mathrm{C}-50 \mathrm{~min}, 85^{\circ} \mathrm{C}-45 \mathrm{~min}$, $85^{\circ} \mathrm{C}-50 \mathrm{~min}, 90^{\circ} \mathrm{C}-40 \mathrm{~min}$ and $90{ }^{\circ} \mathrm{C}-45 \mathrm{~min}$, the formation of zinc borate began but had not completed. Pure zinc borate formed when reaction temperatures and times of $80{ }^{\circ} \mathrm{C}-55 \mathrm{~min}, 85^{\circ} \mathrm{C}-55 \mathrm{~min}, 90^{\circ} \mathrm{C}-50 \mathrm{~min}$
Table 1. XRD results of the synthesized zinc borates

\begin{tabular}{|c|c|c|}
\hline Temperature $\left({ }^{\circ} \mathrm{C}\right)$ & Time (min) & $\mathbf{Z B}$ \\
\hline \multirow[t]{4}{*}{80} & 40 & - \\
\hline & 45 & $36^{*}$ \\
\hline & 50 & $44 *$ \\
\hline & 55 & 64 \\
\hline \multirow[t]{4}{*}{85} & 40 & - \\
\hline & 45 & $45^{*}$ \\
\hline & 50 & $58 *$ \\
\hline & 55 & 65 \\
\hline \multirow[t]{4}{*}{90} & 40 & $54 *$ \\
\hline & 45 & $59 *$ \\
\hline & 50 & 60 \\
\hline & 55 & 68 \\
\hline
\end{tabular}

* Crystal formation was not completed.

and $90{ }^{\circ} \mathrm{C}-55$ min were used. The synthesized zinc borate type was identified as "zinc oxide borate hydrate $\left(\mathrm{Zn}_{3} \mathrm{~B}_{6} \mathrm{O}_{12} \cdot 3.5 \mathrm{H}_{2} \mathrm{O}\right)$ " with a pdf number of "00-0350433".

The XRD patterns of the pure zinc borates are given in Fig. 2a. The highest XRD score, 68, was observed for the specimen synthesized at $90{ }^{\circ} \mathrm{C}-55 \mathrm{~min}$. An XRD score is a measure of the match of the peak intensities (\%) and peak locations of the specimen to the pdf card pattern of the reference mineral. The XRD score of the analysed mineral is equal to $100 .^{26}$

According to Fig. 2a, the characteristic peaks and respective miller indexes (h k l) and d spacing $[\AA]$ of the synthesized zinc borates are given in Table 2 .

Table 2. Miller indexes and d-spacings of the synthesized zinc borates

\begin{tabular}{|c|c|c|}
\hline Peak $\left(^{\circ}\right)$ & Miller index & d spacing $[\AA]$ \\
\hline 17.7 & $11-1$ & 5.88 \\
\hline 18.1 & 020 & 4.90 \\
\hline 20.6 & 101 & 4.30 \\
\hline 21.8 & 120 & 4.08 \\
\hline 23.7 & $12-1$ & 3.74 \\
\hline 25.8 & 210 & 3.44 \\
\hline 28.8 & 012 & 3.10 \\
\hline 30.2 & $22-1$ & 2.95 \\
\hline 36.8 & 230 & 2.44 \\
\hline
\end{tabular}

The observed characteristic peaks agree with the literature. $^{27-28}$

The effect of reaction temperature and reaction time on the formation of zinc borate is shown in Fig. 2b, produced with Statistica 8.0 software (StatSoft Inc., OK, USA). In Fig. 2b, the y-axis is the XRD score, the X-axis is the reaction temperature and the $\mathrm{z}$-axis is the reaction time. Fig. 2b shows that the XRD scores of the zinc bo- 
rates increase with increasing reaction temperature and reaction time.

The same type of zinc borate compound $\left(\mathrm{Zn}_{3} \mathrm{~B}_{6} \mathrm{O}_{12}\right.$. $3.5 \mathrm{H}_{2} \mathrm{O}$ ) was synthesized via a hydrothermal route by Bardakci et al. (2013) from $\mathrm{ZnO}$ and $\mathrm{H}_{3} \mathrm{BO}_{3}$ at $95^{\circ} \mathrm{C}$ with a reaction time of $2 \mathrm{~h} ;{ }^{13}$ Kipcak et al. from $\mathrm{ZnO}$ and $\mathrm{H}_{3} \mathrm{BO}_{3}$ at reaction temperatures and times of $80{ }^{\circ} \mathrm{C}-3 \mathrm{~h}, 90$ ${ }^{\circ} \mathrm{C}-2 \mathrm{~h}$ and $100{ }^{\circ} \mathrm{C}-2 \mathrm{~h} ;{ }^{22}$ Kipcak et al. from $\mathrm{ZnSO}_{4}$. $7 \mathrm{H}_{2} \mathrm{O}, \mathrm{NaOH}$ and $\mathrm{H}_{3} \mathrm{BO}_{3}$ at reaction temperatures and times of $70{ }^{\circ} \mathrm{C}-3 \mathrm{~h}, 80{ }^{\circ} \mathrm{C}-3 \mathrm{~h}, 90{ }^{\circ} \mathrm{C}-2 \mathrm{~h}$ and from $\mathrm{ZnCl}_{2}$, $\mathrm{NaOH}$ and $\mathrm{H}_{3} \mathrm{BO}_{3}$ at reaction temperatures and times of $70{ }^{\circ} \mathrm{C}-4 \mathrm{~h}, 80{ }^{\circ} \mathrm{C}-2 \mathrm{~h}$ and $90{ }^{\circ} \mathrm{C}-2 \mathrm{~h},{ }^{27}$ and Kipcak et al., from $\mathrm{ZnSO}_{4} \cdot 7 \mathrm{H}_{2} \mathrm{O}, \mathrm{Na}_{2} \mathrm{~B}_{4} \mathrm{O}_{7} \cdot 5 \mathrm{H}_{2} \mathrm{O}$ and $\mathrm{H}_{3} \mathrm{BO}_{3}$ at reaction temperatures and times of $70^{\circ} \mathrm{C}-4 \mathrm{~h}, 80{ }^{\circ} \mathrm{C}-4 \mathrm{~h}, 90$ ${ }^{\circ} \mathrm{C}-3 \mathrm{~h}$ and from $\mathrm{ZnCl}_{2}, \mathrm{Na}_{2} \mathrm{~B}_{4} \mathrm{O}_{7} \cdot 5 \mathrm{H}_{2} \mathrm{O}$ and $\mathrm{H}_{3} \mathrm{BO}_{3}$ at reaction temperatures and times of $70{ }^{\circ} \mathrm{C}-4 \mathrm{~h}, 80{ }^{\circ} \mathrm{C}-2 \mathrm{~h}$,
$90{ }^{\circ} \mathrm{C}-2 \mathrm{~h} .{ }^{28}$ Therefore, it is seen that the ultrasonic irradiation method used in this study decreased the reaction times slightly.

\section{3. FT-IR and Raman Spectral Analysis Results for the Synthesized Products}

FT-IR results from the analysis of the zinc borate compounds from selected reactions are shown in Fig. 3a. The bands between $1411 \mathrm{~cm}^{-1}$ and $1252 \mathrm{~cm}^{-1}$ are associated with asymmetric stretching of the three-coordinate boron to oxygen bands $\left[\mathrm{v}_{\mathrm{as}}\left(\mathrm{B}_{(3)}-\mathrm{O}\right)\right]$. The spectral range of $1195 \mathrm{~cm}^{-1}$ to $1112 \mathrm{~cm}^{-1}$ comprises the bending of boronoxygen-hydrogen $[\delta(\mathrm{B}-\mathrm{O}-\mathrm{H})]$. The presence of IR peaks at approximately $1063 \mathrm{~cm}^{-1}$ are due to the asymmetric stretching of the four-coordinate boron to oxygen bands

a)

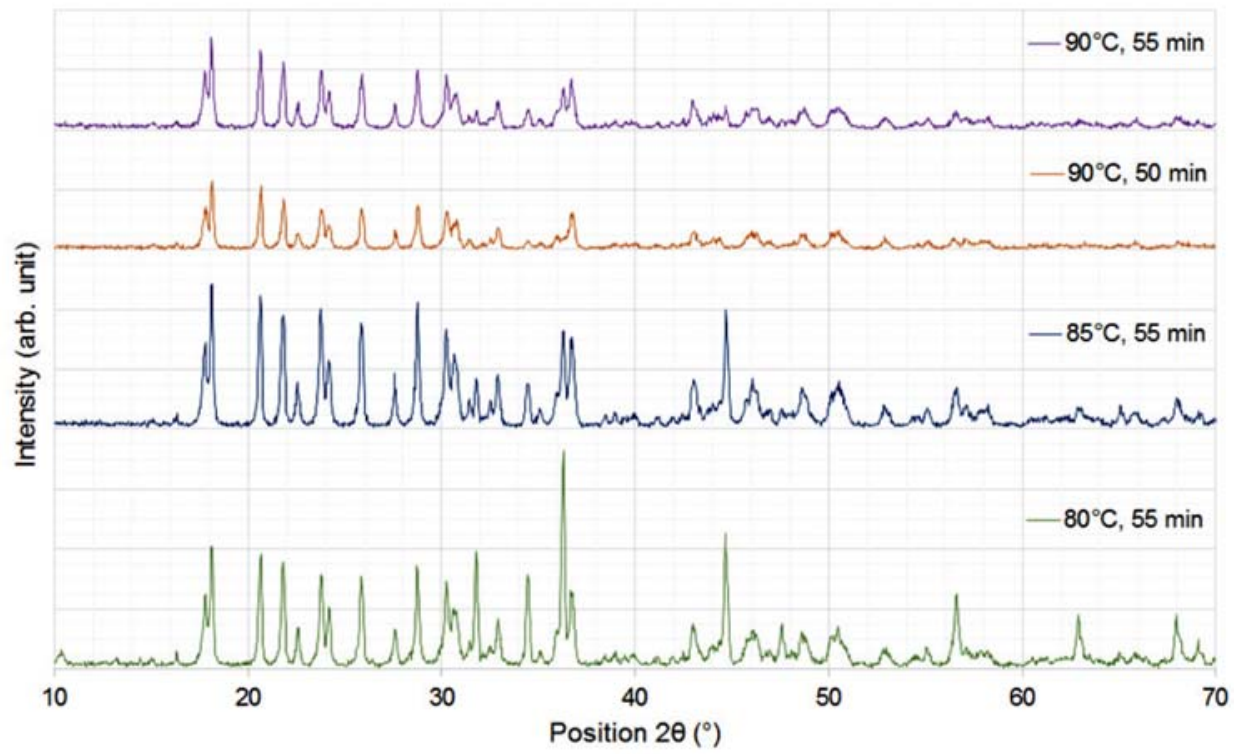

b)

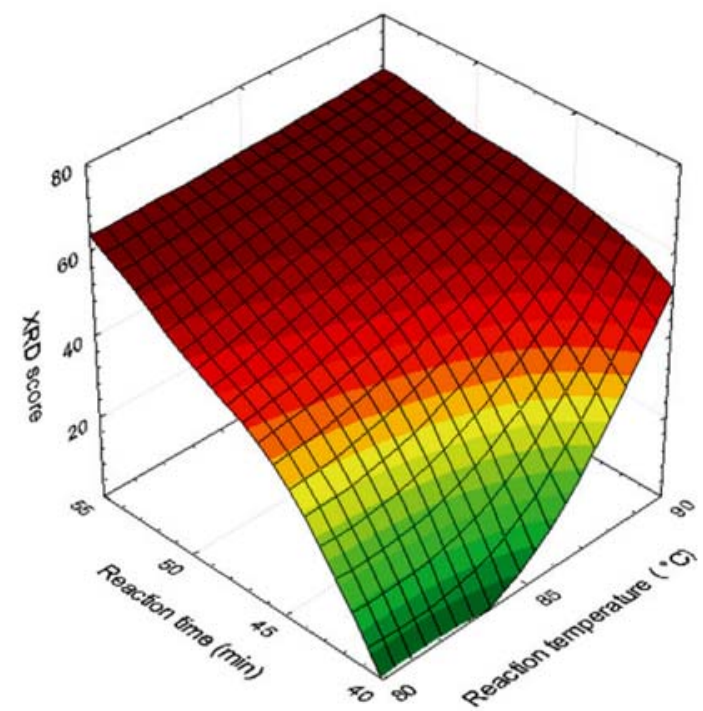

Fig. 2. a. XRD patterns of the synthesized pure zinc borates, b. XRD score graph with respect to reaction temperature and reaction time 
a)

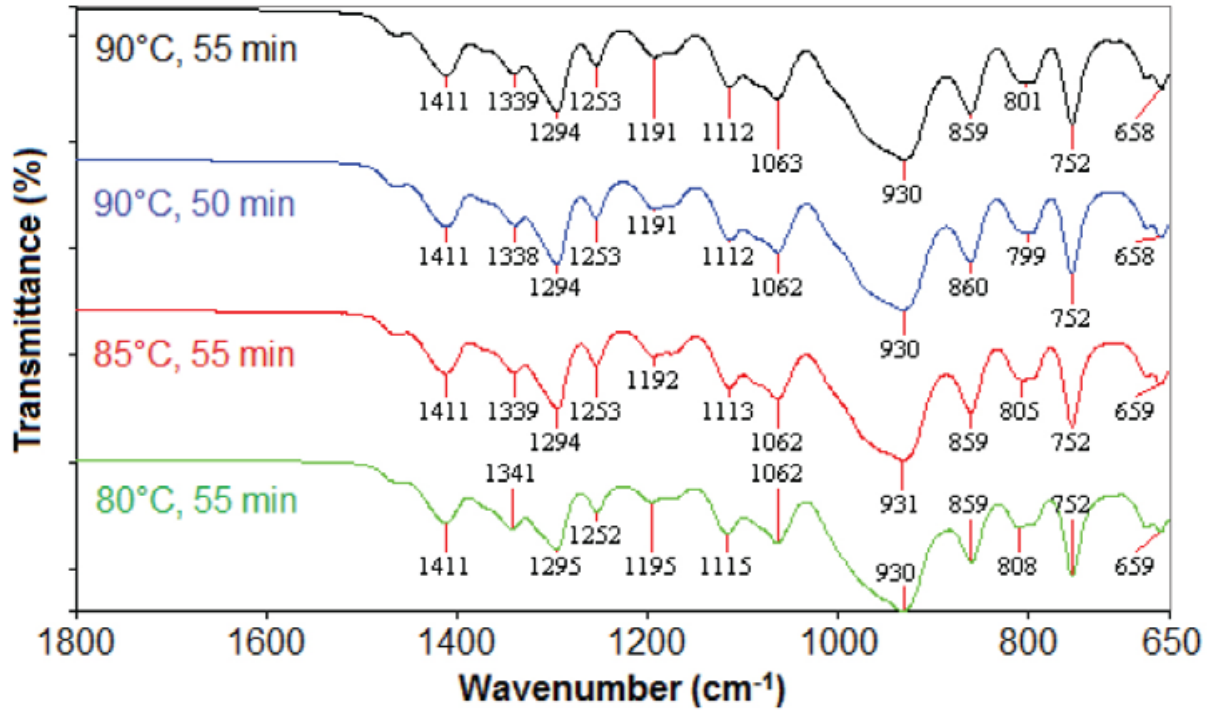

b)

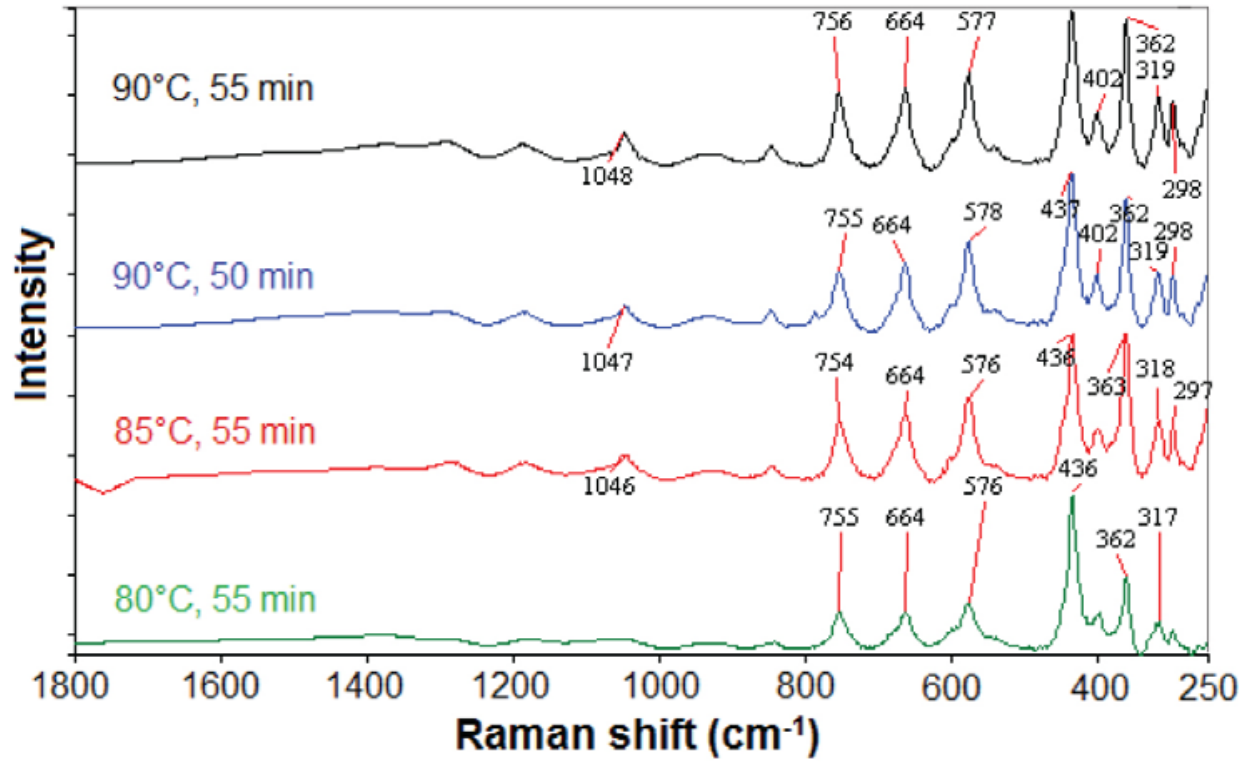

Fig. 3. a. FT-IR spectra of the synthesized pure zinc borates, b. Raman spectra of the synthesized pure zinc borates

$\left[v_{\mathrm{as}}\left(\mathrm{B}_{(4)}-\mathrm{O}\right)\right]$. The peaks at approximately $930 \mathrm{~cm}^{-1}$ are related to the symmetric stretching of three-coordinate boron to oxygen bands $\left[v_{s}\left(\mathrm{~B}_{(3)}-\mathrm{O}\right)\right]$. Between the frequencies of $859 \mathrm{~cm}^{-1}$ and $799 \mathrm{~cm}^{-1}$, the IR peaks are assigned to the symmetric stretching of four-coordinate boron to oxygen bands $\left[v_{s}\left(B_{(4)}-O\right)\right]$. At $752 \mathrm{~cm}^{-1}$, the vibrations that belong to the $\left[\mathrm{v}_{\mathrm{p}}\left(\mathrm{B}(\mathrm{OH})_{4}\right)^{-}\right]$band are recorded. The bending of the three-coordinate boron to oxygen $\left[\gamma\left(\mathrm{B}_{(3)}-\mathrm{O}\right)\right]$ is observed at approximately $659 \mathrm{~cm}^{-1} .^{28}$

The Raman spectra of zinc borate compounds produced from selected reactions are shown in Fig. $3 \mathrm{~b}$.

In the region around $1047 \mathrm{~cm}^{-1}$, the bands of $\mathrm{v}_{\mathrm{as}}\left(\mathrm{B}_{(4)}-\mathrm{O}\right)$ are observed, while the scatterings caused by $v_{\mathrm{p}}\left(\mathrm{B}(\mathrm{OH})_{4}\right)^{-}$appear at approximately $755 \mathrm{~cm}^{-1}$. At 664 $\mathrm{cm}^{-1}$, the peaks belong to the bending of $\gamma\left(\mathrm{B}_{(3)}-\mathrm{O}\right)$, and the peaks of $\left(\mathrm{B}_{(3)}-\mathrm{O}\right) / \delta\left(\mathrm{B}_{(4)}-\mathrm{O}\right)$ bonds are observed below $578 \mathrm{~cm}^{-1} .28$

\section{4. Surface Morphologies and Particle Sizes of the Synthesized Zinc Borates}

The particle morphologies of the synthesized zinc borates were determined by SEM. The SEM images of the selected products are given in Fig. 4. Ultrasonic irradiation produced a uniform particle size distribution with particle sizes between $130 \mathrm{~nm}$ and $506 \mathrm{~nm}$, in contrast to hydrothermal synthesis. ${ }^{22}$ The sub-micron particle size was observed because of the agglomeration effects of Van der Walls forces between the nanoscale zinc borates ${ }^{1}$. A thorn-like particle morphology was observed for speci- 


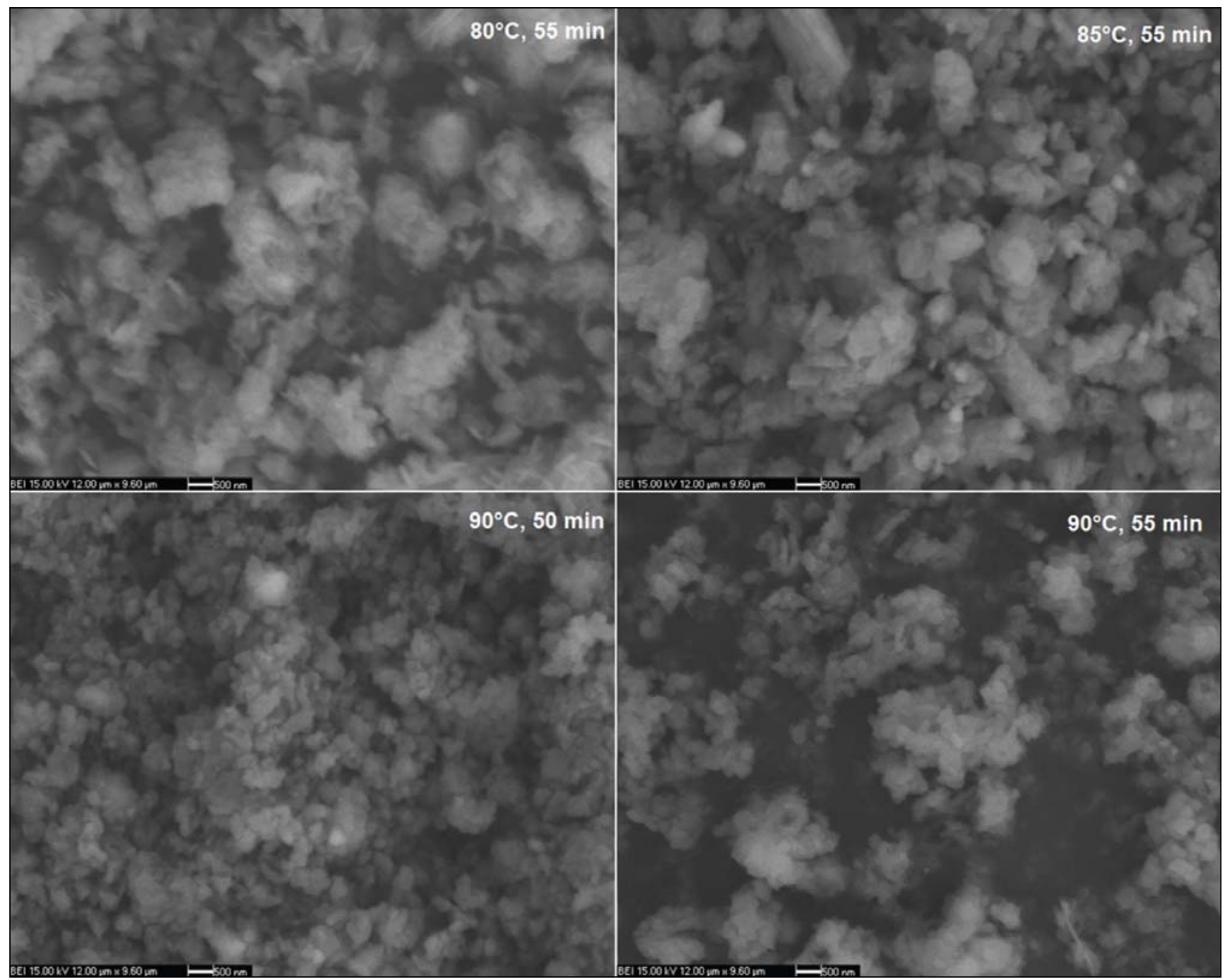

Fig. 4. SEM images of the synthesized pure zinc borates

mens synthesized at $80{ }^{\circ} \mathrm{C}$ for $50 \mathrm{~min}$, but the morphology became rounder with increasing temperature and reaction time.

\section{5. Yield Calculation of Synthesized Zinc Borate Hydrates}

The reaction yields increased with increasing reaction time and reaction temperature. The reaction yields were from $89-95 \%$. The highest reaction yield of $95.0 \pm$ $0.6 \%$ was obtained using a reaction temperature of $90{ }^{\circ} \mathrm{C}$ and a reaction time of $55 \mathrm{~min}$. The other pure compound reaction yields were $93.2 \pm 0.3 \%, 92.4 \pm 0.4 \%$ and $89.1 \pm$ $0.5 \%$ for the reaction temperatures and reaction times of $90{ }^{\circ} \mathrm{C}-50 \mathrm{~min}, 85^{\circ} \mathrm{C}-55 \mathrm{~min}$ and $80{ }^{\circ} \mathrm{C}-55 \mathrm{~min}$, respectively. The reaction yield results show that the phase formation of the raw materials to form zinc borate increases by increasing the reaction time and reaction temperature.

Compared to previous studies that used the same raw materials, ultrasonic irradiation intensifies the reac- tions and enhances the reaction yield even for moderate reaction conditions due to the faster energy and mass transfer afforded by ultrasonic irradiation. ${ }^{13,14}$

\section{6. Zinc Borate Thermal Dehydration Results}

The thermal analysis curves of the dehydration behaviour of $\mathrm{Zn}_{3} \mathrm{~B}_{6} \mathrm{O}_{12} \cdot 3.5 \mathrm{H}_{2} \mathrm{O}$ are given in Fig. 5a. From Fig. 5a, it is seen that the zinc borate compound lost its crystal water $(13.939 \% \mathrm{w} / \mathrm{w}$, that is approximately 3.5 mol of $\mathrm{H}_{2} \mathrm{O}$ ) in a single step over the temperature range of $107.30^{\circ} \mathrm{C}-548.09^{\circ} \mathrm{C}$. The probable dehydration reaction is given in eqn. (6). Table 3 provides the initial temperature $\left(T_{i}\right)$, peak temperature $\left(T_{p}\right)$ and final temperature $\left(T_{f}\right)$ values along with weight losses $(\Delta m)$ calculated from the TG, DTG and DTA data.

$$
\begin{aligned}
& \mathrm{Zn}_{3} \mathrm{~B}_{6} \mathrm{O}_{12} \cdot 3.5 \mathrm{H}_{2} \mathrm{O}(\mathrm{s}) \stackrel{\text { heat }}{\longrightarrow} \mathrm{Zn}_{3} \mathrm{~B}_{6} \mathrm{O}_{12}(\mathrm{~s})+ \\
& \left.+3.5 \mathrm{H}_{2} \mathrm{O} \mathrm{O} \mathrm{g}\right)
\end{aligned}
$$


Table 4. Miller indexes and d-spacings of obtained zinc oxide

\begin{tabular}{|c|c|c|}
\hline Peak $\left(^{\circ}\right)$ & Miller index & d spacing $[\AA ̊ 0]$ \\
\hline 31.76 & 100 & 2.81 \\
\hline 34.42 & 002 & 2.61 \\
\hline 36.25 & 101 & 2.78 \\
\hline 47.54 & 102 & 1.91 \\
\hline 56.59 & 110 & 1.63 \\
\hline 62.85 & 103 & 1.48 \\
\hline 67.94 & 112 & 1.38 \\
\hline 69.08 & 201 & 1.36 \\
\hline
\end{tabular}

a)

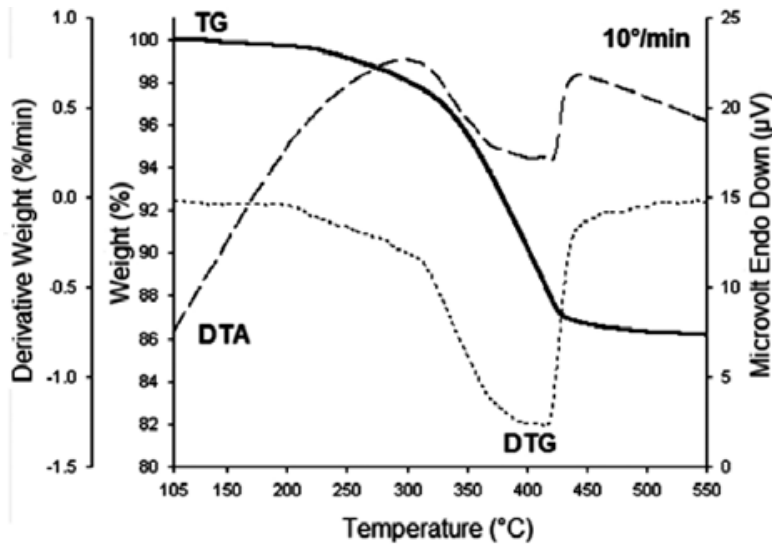

b)

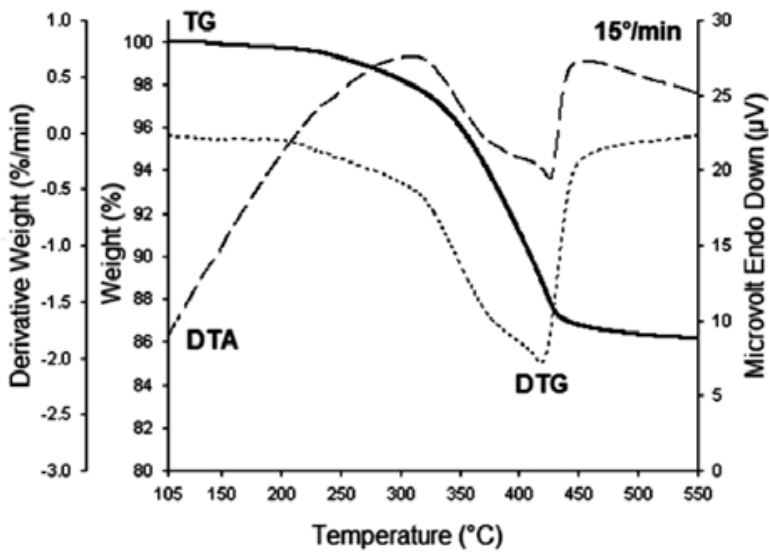

The thermal data obtained from the TG, DTG and DTA curves were applied to the non-isothermal kinetic methods of Doyle and Kissinger to calculate $E_{a}$ and $k_{0}$.

Using the Doyle method, $E_{a}$ is calculated as 341.61 $\mathrm{kJ} / \mathrm{mol}$ from the slope of the line in Fig. $5 \mathrm{~d}$ and $\mathrm{k}_{0}$ values were calculated using eqn. (3) were $2.71 \times 10^{42}, 1.60 \times$ $10^{42}, 8.90 \times 10^{41}$ for $\beta$ values of 10,15 and $20^{\circ} \mathrm{C} . \mathrm{min}^{-1}$, respectively.

Using the Kissinger method, $E_{a}$ was calculated as $390.17 \mathrm{~kJ} / \mathrm{mol}$ using the slope of the line in Fig. 5e, and $k_{0}$ value was calculated using the intercept of eqn. (4) was

d)

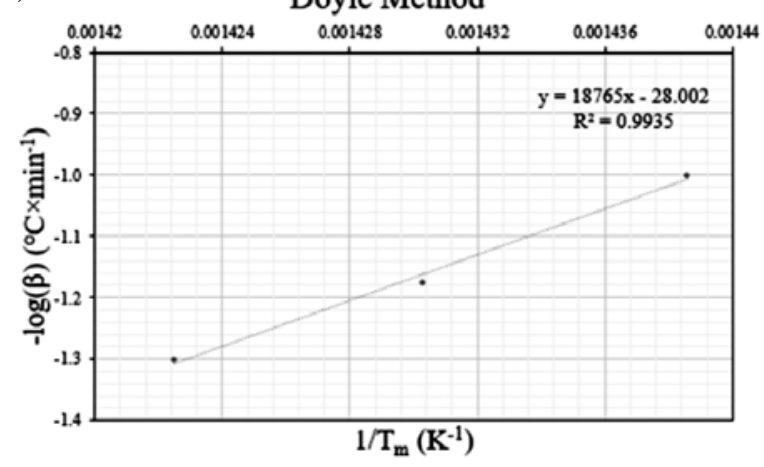

e)

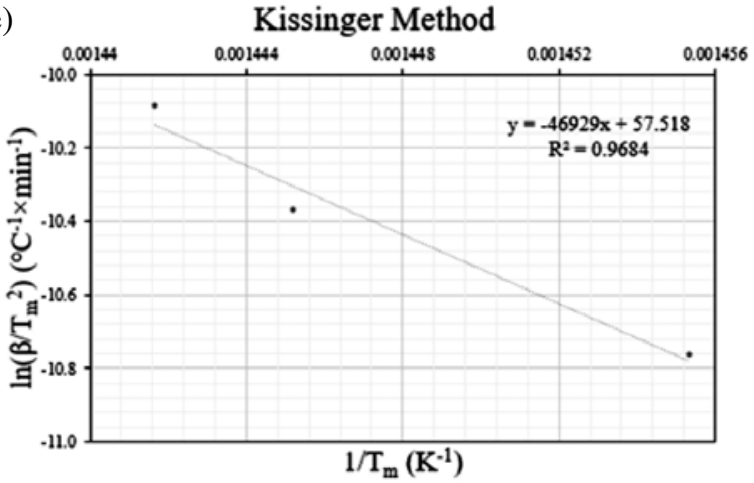

c)

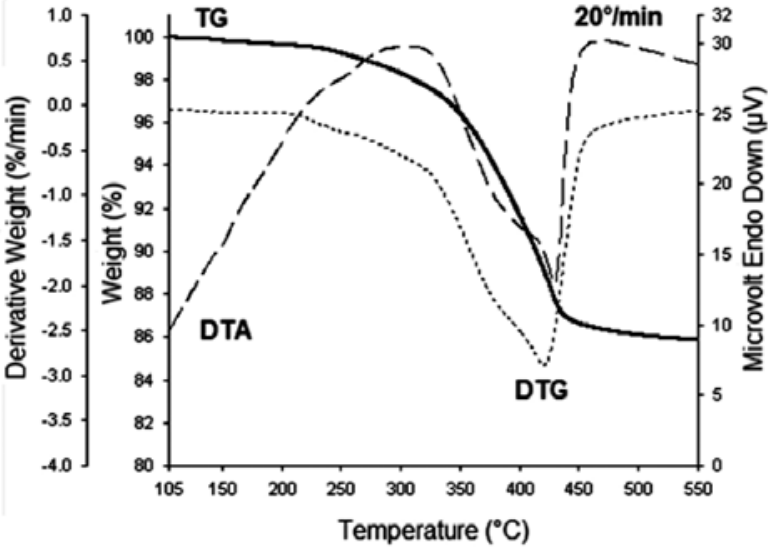

Fig. 5. a. Thermal analysis curves of $\mathrm{Zn}_{3} \mathrm{~B}_{6} \mathrm{O}_{12} \cdot 3.5 \mathrm{H}_{2} \mathrm{O}$, a. at $10{ }^{\circ} \mathrm{C} / \mathrm{min}$, b. at $15{ }^{\circ} \mathrm{C} / \mathrm{min}$, c. at $20{ }^{\circ} \mathrm{C} / \mathrm{min}$, d. Thermal kinetic curves of $\mathrm{Zn}_{3} \mathrm{~B}_{6} \mathrm{O}_{12}$ $3.5 \mathrm{H}_{2} \mathrm{O}$ by Doyle Method, e. Thermal kinetic curves of $\mathrm{Zn}_{3} \mathrm{~B}_{6} \mathrm{O}_{12} \cdot 3.5 \mathrm{H}_{2} \mathrm{O}$ by Kissinger Method. 
$4.48 \times 10^{41}$ for $\beta$ values of 10,15 and $20^{\circ} \mathrm{C} \cdot \mathrm{min}^{-1}$. The $E_{a}$ values obtained from the two different kinetic methods were in good agreement with each other.

\section{7. Zinc Borate Thermal Conversion Results}

The thermal conversion of zinc borate hydrate resulted in a weight loss of $13.10 \%$ during calcination. According to the TG analysis and the theoretical water content of zinc borate hydrate, the weight loss was due to the loss of structural water. By heating the zinc borate hydrate to $550{ }^{\circ} \mathrm{C}$, the compound decomposed into zinc oxide $(\mathrm{ZnO})$ (pdf 01-079-2205) and $\mathrm{B}_{2} \mathrm{O}_{3}$ (pdf 01-072-0626) according to eqn. (7).

$$
\begin{aligned}
& \mathrm{Zn}_{3} \mathrm{~B}_{6} \mathrm{O}_{12} \cdot 3.5 \mathrm{H}_{2} \mathrm{O}(\mathrm{s}) \rightarrow 3 \mathrm{ZnO}(\mathrm{s})+3 \mathrm{~B}_{2} \mathrm{O}_{3}(\mathrm{~s})+ \\
& 3.5 \mathrm{H}_{2} \mathrm{O}(\mathrm{g})
\end{aligned}
$$

After purification with ethanol (96\%), supplied from Merck Chemicals (Merck kgaA, Darmstadt, Germany) (CAS no: 64-17-5), which removed the $\mathrm{B}_{2} \mathrm{O}_{3}$ from the mixture of $\mathrm{ZnO}$ and $\mathrm{B}_{2} \mathrm{O}_{3}$, the remaining $\mathrm{ZnO}$ was analysed by XRD, and the XRD pattern is shown in Fig. 6. Based on the XRD results, the Miller indexes and d-spacings of the obtained zinc oxide are given in Table 4.

\section{Conclusions}

In this study, using a novel method of ultrasonic irradiation, a zinc borate compound of zinc oxide borate hydrate $\left(\mathrm{Zn}_{3} \mathrm{~B}_{6} \mathrm{O}_{12} \cdot 3.5 \mathrm{H}_{2} \mathrm{O}\right)$ was synthesized at several reaction temperatures and times from $\mathrm{ZnO}$ and $\mathrm{H}_{3} \mathrm{BO}_{3}$. In the literature, a reaction temperature of $80{ }^{\circ} \mathrm{C}$ and $2 \mathrm{~h}$ of reaction time were required to synthesize zinc borate. In our study, we synthesized zinc borate in less than $55 \mathrm{~min}$ at several reaction temperatures at a high reaction yield between 89 and $95 \%$. Hence, the reaction times decreased slightly compared to those reported in the literature. FTIR and Raman spectra of the synthesized compound agreed with the literature studies. From the SEM morphological analysis, the particle sizes were between $130 \mathrm{~nm}$ and $506 \mathrm{~nm}$, which are in the scale of sub-micrometre si- ze. Using the methods of Doyle and Kissinger, the activation energy, $E_{a}$, for thermal dehydration of zinc borate was calculated to be 341.61 and $390.17 \mathrm{~kJ} / \mathrm{mol}$, respectively. The zinc borate compound decomposed to $\mathrm{ZnO}$ and $\mathrm{B}_{2} \mathrm{O}_{3}$ after thermal conversion.

\section{Acknowledgments}

This research has been supported by Yıldız Technical University Scientific Research Projects Coordination Department. Project Number: 2015-07-01-YL05.

\section{References}

1. M. Gonen, D. Balkose, R. B. Gupta and S. Ulku, Ind. Eng. Chem. Res., 2009, 48, 6869-6876. https://doi.org/10.1021/ie9003046

2. T. Chen, J. C. Deng, L. S. Wang and G. Feng, J. Mater. Process. Tech., 2009, 209, 4076. https://doi.org/10.1016/j.jmatprotec.2008.09.029

3. D. Gurhan, G. O. Cakal, I. Eroğlu, S. Ozkar, J. Cryst. Growth, 2009, 311, 1545-1552. https://doi.org/10.1016/j.jcrysgro.2009.01.111

4. D. Schubert, F. Alam, M. Visi, C. Knobler, Chem. Mater, 2002, 15, 866-871. https://doi.org/10.1021/cm020791z

5. H. E. Eltepe, D. Balköse, S. Ülkü, Ind. Eng. Chem. Res., 2007, 46, 2367-2371. https://doi.org/10.1021/ie0610243

6. Y. M. Tian, Y. He, L. X. Yu, Y. H. Deng, Y. H. Zheng, F. Sun, Z. H. Liu, Z. C. Wang, Colloids Surf. A, 2008, 312, 99-103. https://doi.org/10.1016/j.colsurfa.2007.06.029

7. B. Garba, Polym. Degrad. Stab., 1999, 64, 517-522. https://doi.org/10.1016/S0141-3910(98)00136-0

8. P. Q. Gao, W. H. Song, X. Wang, Key Eng. Mater., 2013, 567, 87. https://doi.org/10.4028/www.scientific.net/KEM.567.87

9. H. Sawada, H. Igarashi, A. Tatebe, K. Sakao, United States Patent, Patent No: 6,780,913 B2. 2004, 1.

10. Y. H. Gao, Z. Liu, Thermochim. Acta, 2009, 484, 27-31. https://doi.org/10.1016/j.tca.2008.11.013

11. Y. Zheng, Y. Tian, H. Ma, Y. Qu, Z. Wang, D. An, S. Guan, X. Gao, Colloid Surf. A, 2009, 339, 178-184. https://doi.org/10.1016/j.colsurfa.2009.02.018

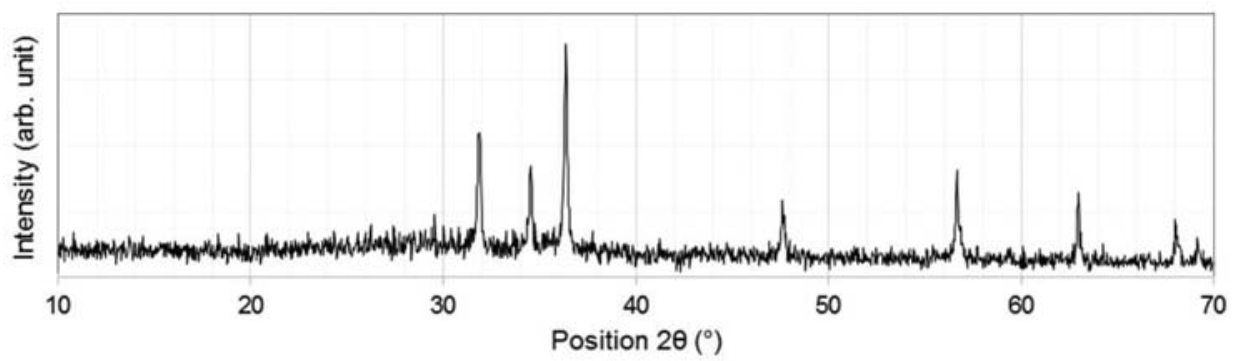

Fig. 6. XRD pattern of $\mathrm{ZnO}$ obtained by after calcination process 
12. N. Tugrul, N. B. Acarali, Int. Conf. Chem. Chem. Proc., 2011, 10, 55-58.

13. M. Bardakci, N. B. Acarali, N. Tugrul, E. M. Derun, M. B. Piskin, Mater. Sci., 2013, 19, 158-163.

14. N. B. Acarali, N. Tugrul, E. M. Derun, S. Piskin, Int. J. Miner. Metall. Mater., 2013, 20, 1081-1088. https://doi.org/10.1007/s12613-013-0837-x

15. R. Mettin, C. Cairo’s, A. Troia, Ultrason. Sonochem., 2015, 25, 24. https://doi.org/10.1016/j.ultsonch.2014.08.015

16. A. S. Kipcak, E. M. Derun, Res. Chem. Intermediat., 2016, 42, 6663-6679. https://doi.org/10.1007/s11164-016-2488-9

17. A. K. Zak, W. H. Majid, H. Z. Wang, R. Yousefi, A. M. Golsheikh, Z. F. Ren, Ultrason. Sonochem., 2013, 20, 395-400. https://doi.org/10.1016/j.ultsonch.2012.07.001

18. W. Kim, D. Choi and S. Kim, Mater. Trans., 2010, 51, 1694-1698. https://doi.org/10.2320/matertrans.M2010191

19. H. Wang, Y. N. Lu, J. J. Zhu, H. Y. Chen, Inorg. Chem., 2003, 42, 6404-6411. https://doi.org/10.1021/ic0342604

20. B. Neppolian, Q. Wang, H. Jung and H. Choi, Ultrason. Sonochem., 2008, 15, 649.

https://doi.org/10.1016/j.ultsonch.2007.09.014
21. M. S. Yılmaz, A. K. Figen, S. Pişkin, Powder Technol., 2012, 215, 166-173. https://doi.org/10.1016/j.powtec.2011.09.043

22. A. S. Kipcak, N. B. Acarali, E. M. Derun, N. Tugrul and S. Piskin, J. Chem., 2014, 2014, Article ID 512164, 1.

23. A. Ersan, A. S. Kipcak, M. Yildirim, A. M. Erayvaz, E. M. Derun, N. Tugrul and S. Piskin, Int. J. Chem. Molecular, Nuclear, Mater. and Metallurgical Eng., 2015, 9, 1327- 1330.

24. D. S. Vardar, A. S. Kipcak, F. T. Senberber, E. M. Derun, N. Tugrul, S. Piskin, Int. Scholarly Sci. Res. Innovation, 2015, 9.

25. H. S. Fogler, Element of Chemical Reaction Engineering, Prentice-Hall, New Jersey, 1999, 3rd edn.

26. T. İbroşka, A. S. Kipcak, S. A. Yuksel, E. M. Derun and S. Piskin, Turk. J. Chem., 2015, 39, 1025-1037. https://doi.org/10.3906/kim-1410-37

27. A. S. Kipcak, F. T. Senberber, E. M. Derun, N. Tugrul and S. Piskin, Res. Chem. Intermediat., 2015, 41, 9129-9143. https://doi.org/10.1007/s11164-015-1952-2

28. A. S. Kipcak, F. T. Senberber, M. Yildirim, S. A. Yuksel, E. M. Derun, N. Tugrul, Main Group Met. Chem., 2016, 39, 59-66. https://doi.org/10.1515/mgmc-2016-0002

\section{Povzetek}

$\mathrm{V}$ prispevku je predstavljena sinteza cinkovega borat hidrata $\left(\mathrm{Zn}_{3} \mathrm{~B}_{6} \mathrm{O}_{12} \cdot 3.5 \mathrm{H}_{2} \mathrm{O}\right)$ iz cinkovega oksida $(\mathrm{ZnO})$ in borove kisline $\left(\mathrm{H}_{3} \mathrm{BO}_{3}\right) \mathrm{z}$ metodo, ki temelji na uporabi ultrazvoka. Za karakterizacijo produktov smo uporabili naslednje tehnike: rentgensko praškovno difrakcijo (XRD), infrardečo spektroskopijo (FT-IR) in ramansko spektroskopijo. Za določevanje vplivov reakcijskega časa in reakcijske temperature na morfologijo produktov smo uporabili vrstično elektronsko mikroskopijo (SEM). Z metodama termogravimetrične analize in diferenčne termične analize (TG / DTA) smo raziskovali kinetiko dehidracije. Podatke smo analizirali z uporabo metod Doyle in Kissinger. Rezultati XRD so potrdili uspešno sintezo $\mathrm{Zn}_{3} \mathrm{~B}_{6} \mathrm{O}_{12} \cdot 3.5 \mathrm{H}_{2} \mathrm{O}$ pri različnih reakcijskih temperaturah in časih. $\mathrm{Z}$ infrardečo in ramansko spektroskopijo produktov pa smo identificirali vrhove, ki so značilni za cinkov borat. Z uporabo metod Doyle in Kissinger smo določili aktivacijski energiji toplotne dehidracije cinkovega borata, ki sta znašali 341,61 kJ / mol in 390,17 kJ / mol. 